\title{
RETROSPECTIVE ESTIMATION FOR QUALITATIVE DETECTION OF COVID -19 (CORONA VIRUS) IN BLOOD SAMPLES THROUGH DOT ELISA
}

\author{
Dr. Prabha Parmar, \\ Biology faculty, \\ Higher Section, St Mary School Ognaj, Ahmedabad, Gujrat \\ Dr. Megha Kansal, \\ Assistant Professor, Khalsa college for Women, \\ Civil Lines, Ludhiana, Punjab
}

\begin{abstract}
In this present pandemic situation across the world wide, India is not deprived of it, like other nation we are also facing the mobilized problem to find out the vaccination for the corona virus. But before its remedy to be found out, one more challenge is there to estimate the patients with corona positive. For a nation with dense population like India our first approach shall be towards the maximum testing of people for concerned virus. In this context the present article is emphasized on, includes previous literature some retrospective estimation of virus detection (plant, animals) techniques with the help of immunological parameters has been observed. Even though so many immuno-techniques are popularly using now days for rapid detection of number of serological tests, but Dot ELISA can be the cheapest, fast and cost effective tool for the qualitative detection of corona virus. This tool will reduce time, labor energy and expenditure up to maximum limit, thereby can make even the lower class people of India able to avail the testing facility for this pandemic disease.
\end{abstract}

\section{KEYWORDS: Dot ELISA, COVID-19, SEROLOGY}

\section{INTRODUCTION}

Recently identified novel coronavirus of zoonotic origin (2019-nCoV) is officially classified as severe acute respiratory syndrome coronavirus 2 (SARS-CoV-2) Alexander et al (2020), ICTV (2020). Corona Virus Disease (COVID-19) is genetically similar to SARS coronavirus and bat SARS-like coronaviruses causing acute respiratory disease via human-to-human transmission Zhu et al (2020), WHO
(2019). Full-genome sequencing and phylogenic analysis indicated that $2019-\mathrm{nCoV}$ is a distinct clade from the beta coronaviruses associated with human severe acute respiratory syndrome (SARS) and Middle East respiratory syndrome (MERS) Yamaoka et al (2016). COVID-19 is an acute resolved disease with a $2 \%$ fatality rate due to massive alveolar damage and progressive respiratory failure. Huang et al (2020), Chan et al (2020).

Serology assays like traditional reverse transcription-polymerase chain reaction (RT-PCR) methodology developed for SARS and MERS are time consuming, resource intensive, complex because proper animal models, protocols, and specific antibodies had to be developed. Gallagher (2020). To develop a sensitive and reliable assay for routine laboratory diagnosis, a rapid dot enzyme-linked immunosorbent assay (dot-ELISA) method can be developed for testing of infected patient by COVID 19. Based on anti COVID-19 rabbit antiserum the Dot ELISA expected to be highly reliable sensitive and specific toward COVID-19 diagnosis. Prabha et al (2017).

\section{DETECTION AND SEROLOGY}

Coronavirus has only 4 structural proteins: the spike (S), membrane (M), envelope (E), and nucleocapsid (N) proteins. Alexender et al (2020).

In the case of COVID-19, the spike protein appears to be the primary protein interacting with host cells. Hence, the spike protein is likely the protein to which antibodies are raised, but this is not clear at this time. 


\section{International Journal of Engineering Applied Sciences and Technology, 2020 \\ Vol. 5, Issue 1, ISSN No. 2455-2143, Pages 616-618 \\ Published Online May 2020 in IJEAST (http://www.ijeast.com)}

Immunofluorescent assay (IFA) shows whether a patient has antibodies to a pathogen by displaying a fluorescent signal when patient antibodies interact with virus proteins. Enzyme-linked immunosorbent assays (ELISAs) are more rapid serology tests that provide a readout of antigen- antibody interactions. Essentially, patient antibodies are "sandwiched" between the viral protein of interest and reporter antibodies, so that any active patient antibodies are detected.

The accuracy of two blotting media, polyvinylidene fluoride membrane (PVDF membrane) and nitrocellulose filter membrane (NC membrane), was compared. In order to facilitate the on-site diagnosis. Wang et al (2012) The Development and Application of a Dot-ELISA Assay for Diagnosis of Southern Rice Black-Streaked Dwarf Disease in the Field. Prabha (2018)

ELISA strips are supplied having three well defined zones:

- Negative control zone that is blocked with an inert protein.

- Test zone having an antibody immobilized on it and then blocked with an inert protein.

- Positive control zone having the antibody immobilized on it, blocked with inert protein and has a specific antigen bound to the immobilized antibody.

Antigen coating 10( $\mu \mathrm{l})$<smiles>[AlH2]</smiles>

Washing of plate with PBS (0.005M,pH 7.4) X 3

Blocking with $1 \% \operatorname{BSA}\left(37^{\circ} \mathrm{C} 1, \mathrm{hr}\right)$

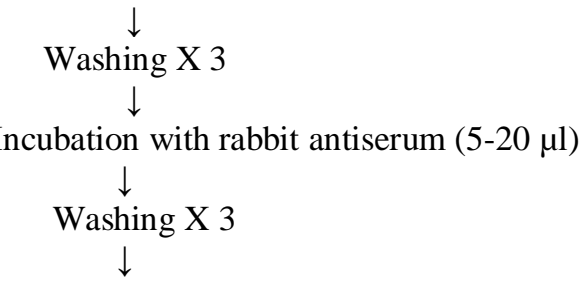

Incubation with secondary antibody (goat anti-rabbit IgG HRP $1 \mathrm{~K}) 37^{\circ} \mathrm{C} 1$, hr

$\stackrel{\downarrow}{\downarrow}$ Enzymatic reaction $(0.04 \%)$ DAB in PBS contains

$0.01 \%$ Hydrogen peroxide $\downarrow$

Stopping the reaction with distilled water $\downarrow$

After absorbance DOT ELISA plate showed development of purple blue colour in the test sample.

\section{DISCUSSION}

Throat swab samples are collected from upper respiratory tract for nucleic acid detection is not standardized, risky for medical staff leading to incompleteness and inaccuracy in updating new cases, as well as delayed diagnosis. Insufficient supply of assay kits creates a demand for fast-performing serologic assay to handle an epidemic of the current scale. Xie et al (2020), Xiang et al (2020). Hopefully, we will begin to understand the viral proteins and immune response to COVID-19 in the coming weeks. Companies and researchers are now working to produce antibodies and antigens of COVID-19. Native Antigen Company, press note (2020). If we will succeed in doing the same DOT ELISA could help in enhancement of rapid qualitative detection of virus with cost effectiveness and reliability at national level.

\section{CONCIUSION}

Detection of corona virus is possible with low and cost effective method by utilizing the immunoassay technique with authentic value and quatitative results.

\section{REFERENCES}

1. Alexander E. G., Susan C. B., Ralph S. B., Raoul J. G., et. al. (2020). The species Severe acute respiratory syndrome- related coronavirus: classifying 2019$\mathrm{nCoV}$ and naming it SARS-CoV-2. Consensus statement, Nature microbiology. (536-544).

2. International Committee on Taxonomy of Viruses. Retrieved February 11, 2020., Vol.: International Committee on Taxonomy of Viruses, 2020. https://talk.ictvonline.org/

3. Zhu N., Zhang D., Wang W., Li X., Yang B., Song J., et al. (2020) A Novel Coronavirus from Patients with Pneumonia in China 2019. N. Engl. J. Med.

4. WHO Director-General's remarks at the media briefing on 2019-nCoV on 11 February 2020. Retrieved February 11, 2020., Vol., 2020. https://www.who.int/dg/speeches/detail/whodirector-general-s-remarks-at-the-media-briefing-on2019-ncov-on-11-february-2020.

5 Yamaoka Y., Matsuyama S., Fukushi S., et al. (2016) Development of monoclonal antibody and diagnostic test for middle east respiratory syndrome coronavirus using cell-free synthesized nucleocapsid antigen. Front Microbiol. (Pg 509). 


\section{International Journal of Engineering Applied Sciences and Technology, 2020 \\ Vol. 5, Issue 1, ISSN No. 2455-2143, Pages 616-618 \\ Published Online May 2020 in IJEAST (http://www.ijeast.com)}

6. Huang C., Wang Y., Li X., et al. (2020). Clinical features of patients infected with 2019 novel coronavirus in Wuhan, China. Lancet. (Pg 497-506).

7. Chan J. F., Yuan S., Kok K. H., et al. (2020). A familial cluster of pneumonia associated with the 2019 novel coronavirus indicating person-toperson transmission: a study of a family cluster. Lancet. (Pg 514-23).

8 Gallagher J. (2020). Are coronavirus tests flawed? BBC News. www.bbccom/ news/health-51491763. Accessed 13 February, 2020.

9 Prabha P., Devinder K. (2017). Development of dot elisa technique for detection of chlorpyrifos and feasibility of its application to field studies. Int. J. Sci. Res. (Pg 1285-1290).

10. Wang Z.1., Yu D., Li X., Zeng M., Chen Z., Bi L., Liu J., Jin L., Hu D., Yang S., Song B. (2012). The development and application of a Dot-ELISA assay for diagnosis of southern rice black-streaked dwarf disease in the field. Viruses. (Pg 167-83).

11. Prabha P. (2018). Standardization and validation of Dot ELISA, finding detection limit of chlorpyrifos in field sprayed samples comparatively to indirect plate ELISA and gas chromatography. Sch. J. App. Med. Sci. (Pg 5014-5026)

12. Xie X., Zhong Z., Zhao W., Zheng C., Wang F., Liu J. (2020) Chest CT for Typical 2019-nCoV Pneumonia: Relationship to Negative RT-PCR Testing. Radiology.

13. Xiang Mingzhe Y., Hongze L., Ting L., Chenyao L., Shuang H., Changxin S. (2020). Evaluation of Enzyme-Linked Immunoassay and Colloidal GoldImmunochromatographic Assay Kit for Detection of Novel Coronavirus (SARS-Cov-2) Causing an Outbreak of Pneumonia (COVID-19). https://doi.org/10.1101/2020.02.27.20028787doi:

14. Native Antigen Company, The Native Antigen Company introduces novel coronavirus antigens [press release]. February $2020 . \quad$ https:// thenativeantigencompany.com/about-us/events/. Accessed February 28, 2020. 